\title{
Sap Production of Paper Birch in the Tanana Valley, Alaska
}

\author{
by \\ Richard A. Ganns, John C. Zasada and Carrol Phillips'
}

\begin{abstract}
Average sap production by paper birch (Betula papyrifera) ranged from 6 to $35 \mathrm{~kg}$ per tree during 2 years of observations. Production during 1977 was 175 percent higher than in 1976. The average carbohydrate concentration of sap was .9 percent and it consisted of 49 percent fructose, 33 percent glucose and 18 percent sucrose.
\end{abstract}

\section{Résumé}

Sur 2 ans d'observations la production moyenne de sève chez le bouleau Blanc Betula papyrifera Marsh) a varié dans les limites de $\mathbf{6}$ à $\mathbf{3 5} \mathbf{~ k g}$ par tige. La production de 1977 a été de $175 \%$ supérieure à celle de l'année 1976. La teneur moyenne en hydrate de carbone de la sève était de $0,9 \%$ avec une proportion de fructose de $49 \%$, de glucose de $33 \%$ et de sucrose de $18 \%$.

The birches (Betula spp. L.) of North America produce sap in the spring, which has the potential to be used for a variety of products. In the Ukraine, sap from several species of birch is used to produce a variety of products including wine, soft drinks, and health drinks (aids). During 1970, almost 2,000 metric tons birch sap were produced in the Volyn region of the Ukraine (see Sendak 1978). Kalinichenko (1974) reported that utilization of sap has increased the per hectare value of birch stands up to 7 -fold over the period of a rotation.

In Alaska, parts of Canada, and the continuous United States, birch is tapped to a limited extent and the sap used primarily for the production of syrup, wine, and beer for home use. Sap production in birch in North America has been the subject of limited study (Parker 1964, Kramer and Kozlowski 1979). This study conducted in 1976 and 1977 characterized and quantified sap production in the Tanana Valley near Fairbanks, Alaska (lat. $64^{\circ} 51 \mathrm{~N}$, long $148^{\circ} 44^{\prime} \mathrm{W}$ ).

\section{Methods and Study Areas}

This study was conducted near Fairbanks, Alaska (latitude $64^{\circ} 51^{\prime} \mathrm{N}$, longitude $148^{\circ} 44^{\prime} \mathrm{W}$ ) in four paper birch stands. Three stands were in the Bonanza Creek Experimental Forest located about $40 \mathrm{~km} \mathrm{SW}$ of Fairbanks; the fourth (Phillips site) is about $5 \mathrm{~km} \mathrm{~N}$ of Fairbanks. Stand and site characteristics for the four study areas are shown in Table 1. The understory tall shrubs at the Bonanza Creek sites were dominated by alder, while willow dominated the Phillips site.

The Phillips study site has been tapped since 1968. At the present time about 400 trees are used for sap production. Sap from about 50 percent of these trees is brought to a central collection point with tubing while the remainder is collected from each tree by hand. Syrup is produced by a two-stage evaporation process. The first stage reduces the sap volume by about 96 percent ( 285 liters per run) and lasts, $1-1 / 2$ to 2 hours. The second step, which uses a steam kettle, reduces the 11 liters of concentrated sap from step 1 to 4 liters of syrup, and takes about 30 minutes. Steam used for boiling is produced in a wood-fired boiler. Steam pressures of $12-14$ grams/square centimeter result in the sap being boiled at $106^{\circ} \mathrm{C}$. The Bonanza Creek sites are natural forests which have not received any management treatment and have never been tapped.

On each of the four sites, sample tree selection was based on the following criteria: diameter at breast height of 20 $\mathrm{cm}$ or greater, large vigorous crown, freedom from obvious disease, and proximity to other trees. At the Phillips site, 37 trees were sampled in 1976 and $1977 ; 10$ trees were sampled at each Bonanza Creek site in 1977.

Tap holes were drilled $3-4 \mathrm{~cm}$ deep and spouts (one per tree) set in these holes. The sap flow was collected in pails or plastic bags. At the Phillips site, sap was weighed (nearest .05 kg) every other day in 1976 and daily in 1977. Bonanza Creek was visited daily. Sap was collected from the time production started until cloudy sap was produced. Once sap becomes cloudy, about the time of bud-break, it cannot be used for syrup with the technology currently available in Alaska. Depending on the tree, sap flow may continue for 3-7 days after it turns cloudy. Thus the variable

Table 1. Site and stand characteristics for four birch stands near Fairbanks Alaska in which sap production was measured.

\begin{tabular}{|c|c|c|c|c|c|c|c|c|c|c|c|c|}
\hline \multirow[b]{3}{*}{ Site } & \multicolumn{4}{|c|}{ Site variables } & \multicolumn{8}{|c|}{ Stand variables } \\
\hline & \multirow{2}{*}{$\begin{array}{c}\text { Stand } \\
\text { age } \\
\text { (years) }\end{array}$} & \multirow{2}{*}{$\begin{array}{c}\text { Slope } \\
(\%)\end{array}$} & \multirow[t]{2}{*}{ Aspect } & \multirow{2}{*}{$\begin{array}{c}\text { Eleva- } \\
\text { tion } \\
\text { (m) }\end{array}$} & \multicolumn{4}{|c|}{ Birch } & \multicolumn{2}{|c|}{ White spruce } & \multicolumn{2}{|c|}{ Black spruce } \\
\hline & & & & & $\begin{array}{c}\text { Stemsl } \\
\text { ha }\end{array}$ & $\begin{array}{l}\text { Ht. domi- } \\
\text { nants } \\
\text { (m) }\end{array}$ & $\begin{array}{l}\text { Avg. } \\
\text { dbh } \\
(\mathrm{cm})\end{array}$ & $\begin{array}{c}\text { Basal } \\
\text { area } \\
\text { m²/ha }\end{array}$ & $\begin{array}{c}\text { Stemsl } \\
\text { ha }\end{array}$ & $\begin{array}{l}\text { Avg. } \\
\text { dbh }\end{array}$ & $\begin{array}{c}\text { Stemsl } \\
\text { ha }\end{array}$ & $\begin{array}{l}\text { Avg. } \\
\text { dbh }\end{array}$ \\
\hline $\begin{array}{l}\text { Phillips } \\
\text { Bonanza Cr. }\end{array}$ & 55 & level & $\mathrm{S}^{\mathrm{a}}$ & 154 & 316 & 15.4 & 17.5 & 13 & 17 & 13.8 & 0 & - \\
\hline Ridge top & 130 & 40 & $E$ & 370 & 662 & 17.5 & 16.8 & 40 & 111 & 10.7 & 62 & 5.8 \\
\hline Mid-slope & 130 & 30 & $E$ & 231 & 358 & 23.1 & 25.4 & 42 & 44 & 19.8 & 0 & 0 \\
\hline Lower slope & 135 & 10 & $E$ & 123 & 316 & 23.1 & 27.9 & 22. & 5 & 6.4 & 0 & 0 \\
\hline
\end{tabular}

asite level but located at the bottom of a major south-facing ridge system.

1 The authors Richard A. Ganns and John C. Zasada, are with the Institute of Northern Forestry, USDA Forest Service, Fairbanks, Alaska; Carroll Phillips is self-employed and resides in Fairbanks, Alaska. 


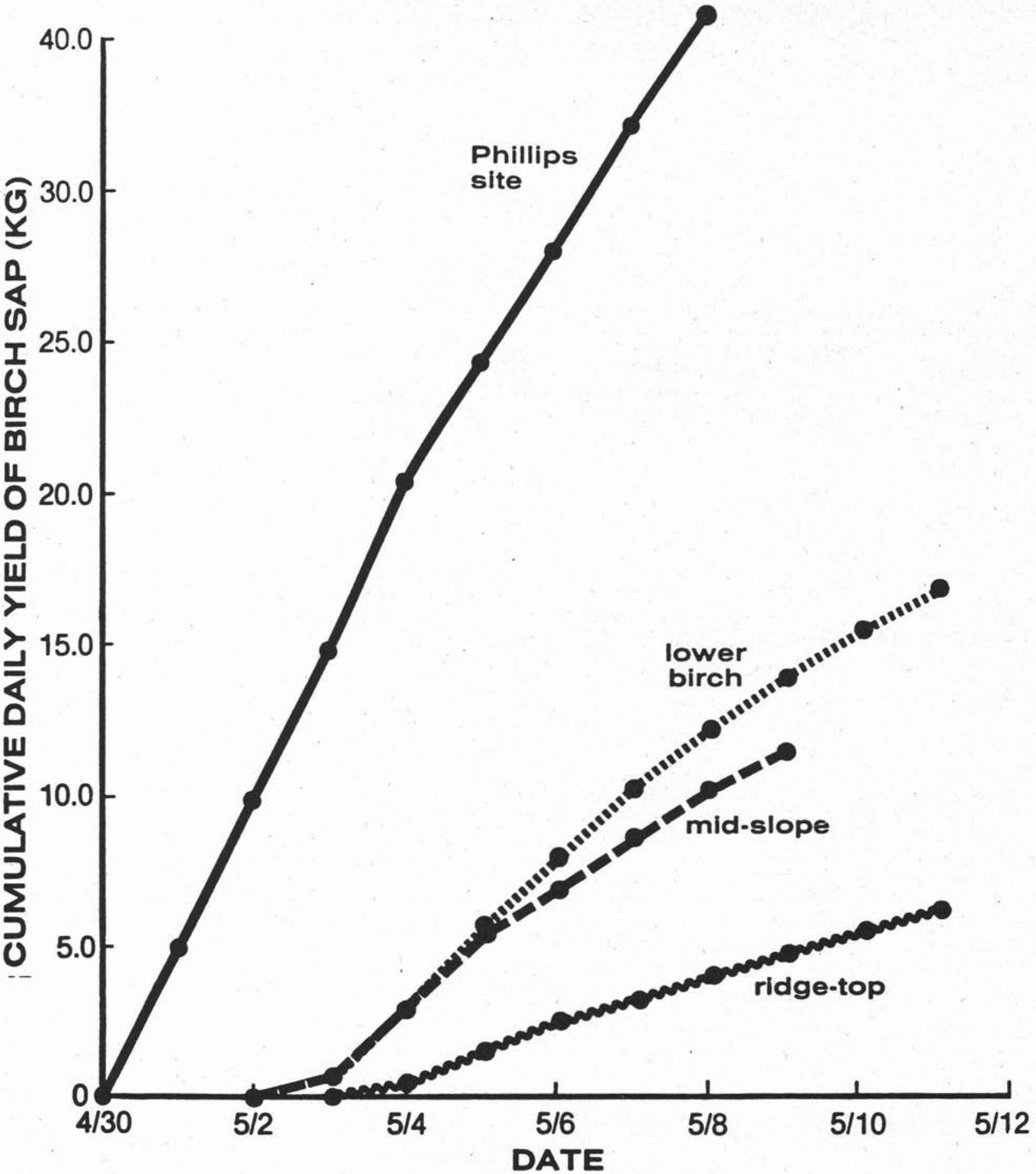

Fig. 1. Cumulative daily sap yield per tree during the 1977 season.

measured in this study is best described as that which is usable for syrup production with the technology currently available.

Sap samples were collected from three trees at the Phillips site in 1976. Immediately following collection, samples were sterilized, frozen, and shipped to the University of Vermont for analysis. ${ }^{2}$ Total solids are calculated from chromatograph data giving percent glucose, fructose and sucrose in the sap and the invert sugar data. The calculation assumes that solids in the xylem sap are composed entirely of sugars. Invert sugars were determined by AOAC titration method with Fehling's solution. Total phenol reacting compounds determined by the folin method (Lowry et al 1951). Total amino nitrogen determined by the fluorescence method using a fluorimeter (Underfriend et al. 1972). Mineral elements were analyzed by an atomic absorption spectrophotometer (Perkin-Elmer 503).

\footnotetext{
${ }^{2}$ Analysis of the sap was conducted in Dr. Mariafranca Morsellis' laboratory at the University of Vermont, Burlington, Vt. We thank Paul E. Sendak, USDA Forest Service, Northeastern Forest Experiment Station, South Burlington, Vt. for arranging to have these samples analyzed.
} 


\section{Results and Discussion}

Sap flow began between April 20 and 23 at the Phillips site in 1976 and April 30, 1977. At the Bonanza Creek sites, sap flow started several days later than at the Phillips site, and was slightly later at the ridgetop site than the lower elevation sites (Figure 1). Sap became cloudy on May 1, 1976, and May 8, 1977, at the Phillips site and several days later. at the Bonanza Creek sites. Viereck (personal communication) ${ }^{3}$ has observed sapflow over a 10-year period in an area similar to the Phillips site. During this period, the timing of sap flow has been as follows:

\begin{tabular}{cccccc}
\multicolumn{2}{c}{ Start of flow } & \multicolumn{2}{c}{ End of flow } \\
Earliest & Latest & Earliest & Latest \\
12 April 1973 & 5 May 1972 & 29 & April 1976 & 20 & May 1972
\end{tabular}

In 1976 the beginning and end of flow at this site were similar to Phillips site while 1977 was 2 days later in starting and 6 days later in ending. In the Volyn region of the Ukraine, birch sap flow begins between April 10-30 and lasts 18 to 20 days (Kalinichenko 1974).

Mean air temperature at the Phillip's site during the 1976 sap collection period was $11^{\circ} \mathrm{C}$ and $7^{\circ} \mathrm{C}$ in 1977 . Air temperatures varied from $-2^{\circ}$ to $23^{\circ} \mathrm{C}$ during this period in 1976 and $-2^{\circ}$ to $11^{\circ} \mathrm{C}$ in 1977 . Soil temperatures in 1977 were $4^{\circ}$ and $2^{\circ} \mathrm{C}$ at 5 and $10 \mathrm{~cm}$, respectively, below the surface of the organic layer; below $15 \mathrm{~cm}$, temperatures were $0 \% \mathrm{C}$ or colder. Frost depth was $51 \mathrm{~cm}$. Depth of the organic layer was $14 \mathrm{~cm}$.

Production of sap at the Phillips site in 1977 (35 kg/tree) was 175 percent greater than the 1976 (20 kg/tree) production. Yield at the Phillips site was greater in 1976 and 1977 than at any of the Bonanza Creek sites in 1977 where production was 6,11 and $16 \mathrm{~kg} /$ tree for ridge, midslope and lower slope sites respectively. There was high tree to tree variation in 1976 and 1977 at the Phillips site and the range in Bonanza Creek sap yield was entirely within the range of the Phillips yield. Average sap yield per tree at Bonanza Creek decreased with increasing elevation; these differences were statistically significant $P=.01$, (Table 2$)$.

Table 2. Birch sap yield for four stands in the Tanana Valley, Alaska.

\begin{tabular}{|c|c|c|c|c|}
\hline \multirow[b]{2}{*}{ Site } & \multirow[b]{2}{*}{$\begin{array}{l}\text { No. of } \\
\text { trees }\end{array}$} & \multicolumn{3}{|c|}{ Sap yield $(\mathrm{Kg})$} \\
\hline & & Mean & $\begin{array}{l}\text { Standard } \\
\text { error } \\
\text { of mean }\end{array}$ & Range \\
\hline \multicolumn{5}{|l|}{ Phillips } \\
\hline 1976 & 37 & 19.7 & 2.1 & $2 \cdot 44$ \\
\hline 1977 & 37 & 35.1 & 3.7 & $0-93$ \\
\hline \multicolumn{5}{|c|}{ Bonanza Creek (1977) } \\
\hline Ridgetop & 10 & 6.1 & 1.1 & $2 \cdot 12$ \\
\hline Mid-slope & 10 & 11.4 & 3.1 & $3-35$ \\
\hline Lower slope & 10 & 16.5 & 1.8 & $7 \cdot 24$ \\
\hline
\end{tabular}

Alaska birch sap yield, as measured in this study, falls within the range reported in the literature. Kramer and Kozlowski (1979) reported production from less than 20 to over 100 liters. Sendak (1978) cited yields ranging from 85 to 170 liters of sap for birch in Russia. Caution must be exercised in making direct comparisons because of such variables as number of taps per tree and the termination of sap flow may have been based on different criteria than those used in this study. Use of the time at which sap turned "cloudy", as used in this study and some Ukrainian reports (Kalinichenko

\footnotetext{
${ }^{3}$ Personal communication with Dr. L. A. Viereck, Institute of Northern Forestry, USDA Forest Service, Fairbanks, Alaska.
}

1974), underestimates the total quantity of sap that could be collected. Golubev et al. (1978) have found that increased turbidity (clouding) of the sap of Betula verrucosa is associated with a significant increase in the number of yeast cells.

Variation at the Phillips site between 1976 and 1977 provides some insight into tree to tree variation. For example:

1. Although total production in 1977 was more than that in 1976 , about 19 percent of the trees produced less sap in 1977. Average reduction in yield for these trees was 14 percent (range 3-25 percent).

2. Seasonal course of sap production between the 2 years differed more for some trees than for others. In one tree, production by day 2 in 1977 was 49 percent of total yield while, in 1976, it was 28 percent. In another tree, yield by day 4 was about 50 percent for both years.

3. Ranking the Phillips trees by 1976 and 1977 production showed that some trees were relatively high or low producers in both years or their ranking was not consistent between years.

4. Tree size (dbh range 20 to $41 \mathrm{~cm}$ ) was not related to yield in this study. It might have been more highly correlated if trees less than $20 \mathrm{~cm}$ dbh had been included in the study. Korolyak and Tomchuk (1973) reported that sap yield in birch was correlated with diameter.

Table 3. Chemical composition of Alaskan birch sap.

\begin{tabular}{lrrr}
\hline & \multicolumn{3}{c}{ Tree number } \\
\cline { 2 - 4 } & $\# 53$ & $\# 60$ & \multicolumn{1}{c}{$\# 71$} \\
\hline pH & 7.1 & 7.1 & 7.4 \\
Percent solids (by weight) & 0.6 & 0.8 & 1.3 \\
Percent invert sugars (by weight) & 0.4 & 0.7 & 1.3 \\
Phenols (ppm) & 64.7 & 69.2 & $>90.5$ \\
Amino nitrogen (ppm) & 4.1 & 5.9 & 2.6 \\
$\mathrm{Ca}(\mathrm{ppm})$ & 30.5 & 12.3 & 14.8 \\
$\mathrm{Mg}(\mathrm{ppm})$ & 11.0 & 6.0 & 6.0 \\
$\mathrm{~K}(\mathrm{ppm})$ & 106.8 & 65.3 & 97.0 \\
$\mathrm{Na}(\mathrm{ppm})$ & .9 & .6 & .2 \\
$\mathrm{Cu}(\mathrm{ppm})$ & .1 & .1 & .1 \\
$\mathrm{Fe}(\mathrm{ppm})$ & .2 & .2 & .2 \\
$\mathrm{Mn}(\mathrm{ppm})$ & 1.2 & 1.0 & .7 \\
$\mathrm{Zn}(\mathrm{ppm})$ & 1.1 & .4 & .7 \\
$\mathrm{Mo}(\mathrm{ppm})$ & .2 & .2 & .4 \\
$\mathrm{Cd}(\mathrm{ppm})$ & - & - & - \\
$\mathrm{Co}(\mathrm{n})$ & .1 & .1 & .2 \\
$\mathrm{~Pb}(\mathrm{ppm})$ & .2 & .2 & .1 \\
\hline
\end{tabular}

The proportion of carbohydrates (solids) in birch sap ranged between .6 and 1.3 percent (Table 3). The average carbohydrate content for maple syrup is usually 2-3 percent (Sendak 1978). In maple sap, sucrose comprised 99 percent of the total solids while in the three Alaska birch sampled in this study, sucrose content averaged 18 + per cent. Fructose and glucose made up the bulk of the solids comprising $49 \pm 5$ and $33 \pm 7$ percent respectively.

The sap concentration process used by Phillips, and briefly described earlier, resulted in a product with a $\mathrm{pH}$ of 5.2 , 54-percent solids, phenol concentration of $14,500 \mathrm{ppm}$ and amino $\mathrm{N}$ concentration of $264 \mathrm{ppm}$. These values were substantially different than the untreated sap $(\mathrm{pH} 7.2$, total solids .9 percent, phenols $75 \mathrm{ppm}$ and amino nitrogen $4 \mathrm{ppm}$ (Table 3).

Inorganic constitutents of birch sap varied considerably among trees. For 5 of 12 elements examined, there was 200-to 400-percent difference between the highest and lowest values. Of the elements tested, potassium concentration was highest in two trees (Table 3).

The results of this study provide quantitative data on the annual production of birch sap at the northwestern end of the range of paper birch. The data suggest that the biological potential exists for production of significant quan- 
tities of sap for use in the production of several products that might be of value for local use in communities in Alaska.

\section{References}

Golubev, V.I., I.P. Bab'eva, and S.N. Novik. 1978. Yeast succession in birch sap flows. Soviet J. of Ecol. 8(5): 399-403.

Kalinichenko, A.A. 1974. Sap productivity of some species of birch. Rastitel'nye Resursy 10(1): 117-120.

Korolyak, I.S., and R.I. Tomchuk. 1973. Sapflow in birch in relation to stem diameter, air temperature, date of tapping and time of day. Lesnoi Zhurnal 16(6): 27-33.
Kramer, P.J. and T.T. Kozlowski. 1979. Physiology of woody plants. Academic Press. New York. 811 p.

Lowry, O.H., N.J. Rosebrough, A.L. Farr, and R.J. Randall. 1951. Protein measurement with folin phenol reagent. J. Bio. Chem. 193: 265-275.

Parker, J. 1964. Autumn exudation from black birch. Scientific Tree Topics 2(10): 9-11. (Published by Bartlett. Tree Research Laboratories.)

Sendak, Paul E. 1978. Birch sap utilization in the Ukraine. J. For. 76: 120-121.

Underfriend, S., S. Stein, P. Bohlen, W. Dairman, W. Leimgruber and M. Weigele. 1972. Fluorescamine: A reagent for assay of amino acids, proteins, and primary amines in the picomole range. Science 78: 871-872.

Une nouvelle responsabilité s'est ajoutée aux autres. L'inflation est une réalité de la vie dont chacun se doit de tenir compte dans sa planification familiale.

Avez-vous pensé à la protection que votre assurance vie IFC prévoit pour votre famille? Avezvous pensé au coût de la vie croissant? Si vous n'étiez assuré que pour le capital minimum, soit $10000 \$$, il est certain que votre famille ne survivrait pas longtemps!

Les membres de I'IFC et leur famille peuvent être assurés pour 100000 \$, jusqu'à l'âge de 50 ans, à des taux de prime avantageux. Si vous n'avez pas songé à augmenter votre protection, il serait peut-être avisé de reconsidérer de façon plus réaliste votre programme d'assurance vie IFC.

L'Institut Forestier du Canada a tous les détails. Son adresse est 151, rue Slater, pièce 815, Ottawa (Ontario) K1P $\mathbf{5 H 3}$. 